\title{
E-Schools Development In Filial Schools As A Solution To Improve Teaching And Learning Activities And The Effectiveness Of School Administration
}

\author{
Febrianty ${ }^{1}$, Hendra Hadiwijaya ${ }^{2 *}$, D. Tri Octafian ${ }^{3}$ \\ 12 Palcomtech Polytechnic, Indonesia \\ ${ }^{3}$ Palcomtech STMIK, Indonesia \\ Email: febrianty@palcomtech.ac.id, hendra hadi@palcomtech.ac.id, d.trioctafian@gmail.com
}

\begin{abstract}
Lembaga Pembinaan Khusus Anak (LPKA) Class I Palembang is a pilot LPKA throughout Indonesia that has successfully implemented distance learning / filial schools with the same standards as the main schools (technical learning management schools) in collaboration with the Palembang City Education Office, Palembang City Government and Provincial Government of South Sumatra. LPKA Class I Palembang organizes formal education (filial schools) starting from elementary, middle, and high school levels. The purpose of this study is to build an e-school system as an alternative in overcoming problems in the teaching and learning process and academic administration of schools. The system development method used in this study is the Rapid Application Development (RAD) method, with the following stages: Requirements Planning, RAD Workshop Design, and Implementation. The results of this study are children's e-school systems so that it becomes a solution for LPKA Class I Palembang in implementing learning and improving the quality of children's learning.
\end{abstract}

Keywords: school, e-school, filial, LPKA Class I, Palembang

\section{Introduction}

Lembaga Pembinaan Khusus Anak (LPKA) Class I Palembang is a pilot LPKA in Indonesia that has successfully implemented distance learning/filial schools with the same standards as the umbrella schools (technical, learning, and management of schools) in collaboration with the Education Office, Palembang City Government and South Sumatra Province Government. The mechanism for filial school implementation is based on an MOU with the Mayor of Palembang and recommendations from the Head of the Education, Youth and Sports Office in 2014. LPKA Class I Palembang organizes formal education (filial schools) at the elementary, middle and high school levels. The current umbrella schools are all A-accredited schools, namely: SDN 25, SMPN 22, and SMAN 11 in the Palembang region. Even LPKA also continues to facilitate children who are free but have not finished school to continue their studies at the filial school. LPKA officers only assist administration, security and order supervision. The filial school program is an effort to fulfill the right to education for LPKA children to learn with the pattern of inclusive development, according to EFA (Education for All) aims to fulfill the educational rights of every child, adolescent every

\footnotetext{
${ }^{*}$ Corresponding author.
}

Received 02 April 2020; Accepted 10 July 2020; Available online 01 September 2020 (C) 2020 JPI. All Rights Reserved 
adult. Providing Education For All, getting the education provided must be flexible and adapted to the needs of the people who study it (Twin, 2017).

Although the LPKA school is a pilot school, there are obstacles, namely: teachers who are active in teaching \pm 40 people even though 72 people are registered. This is due to the reluctance of teachers to teach in filial schools even though students have a high enough enthusiasm to learn. Even though the subject schedule is the same as the umbrella school, the learning atmosphere and quality of learning are not the same. Short school hours and learning methods that adjust the psychological conditions of students even though students want to keep getting similarities in the teaching-learning process like in the umbrella school. Likewise, the management of LPKA Class I Palembang wants to present academic services through the provision of a system that can support better education. There is a strong desire of the LPKA management to also transmit and develop the filial school system to other LPKA (based on the results of the interview on 10 September 2018 with Head of the LPKA Class I Palembang and Head of Education and Skills). In 2018, as of September 2018, there were 130 students in the LPKA. LPKA Class I Palembang is known for its achievement and innovation but the LPKA still has limitations in organizing filial schools, especially in the use of information technology.

Based on the problems of LPKA Class I Palembang, an effective and efficient learning system is needed by applying filial e-school. Because E-learning offers various benefits that can make it an alternative improvement for face-to-face training, e-learning also provides results comparable to face-to-face learning that makes students active and also the learning process that suits the needs of motivator educators and student learning methods (Widhiartha, 2009). E-learning is a learning tool that is increasingly in demand, so it is often used in the Distance Education system (PJJ) (Soekartawi, 2007). e-learning is defined as sending learning materials through electronic media namely: internet, intranet/extranet, satellite broadcast, audio/videotape, interactive TV, CD-ROM, and Computer-Based Training (CBT) (Gilbert \& Jones, 2011). e-learning can also shorten the target timetable for learning, and certainly save the costs that must be spent by study programs or educational programs (Ali, 2009). e-School is a web-based school management information system that consists of various application modules that function to manage all academic administration and management activities in a school. The initial stage of developing the School Information System will be focused on Academic Data Management (Students, Teachers, Curriculum, Score, Attendance) (Putra et al., 2019). Furthermore, additional features can be made for Financial Management, School Accreditation Reporting, Equipment, Library data, SMS (Short Message Service), and Alumni (Wahyudi \& Diana, 2012). e-School is a combination of integrated software applications used by schools for student data management, automatic processing of grades, report formation, and other supporting reports in accordance with the standards of the National Education Office, and the process of distributing information directly to students and parent, either through e-mail or website. In addition, with supporting features of e-Learning for schools, it is hoped that this system can guarantee to advance the quality of education in LPKA Class I Palembang.

Research Mawardi et al., (2012). regarding the study of web-based application design Learning Systems (LMS) web-based, the LMS method was chosen to make school materials online and manage learning activities and their results (Mawardi et al., 2012). LMS serves to 
store, manage, and distribute various training materials and examinations that have been prepared. E-learning is a web-based learning ecosystem for the dissemination of information, communication, and knowledge for education and training (Cidral et al., 2018).

Research by Wahyudi and Diana, where the e-School system was designed using UML and for its implementation using PHP and MySQL (Wahyudi \& Diana, 2012). The webbased e-school system consists of various modules including the New Student Admission module (PSB), learning module, staffing module, and guidance module. This research was also developed as a continuation of previous research conducted (Kosasi \& Yuliani, 2015). The study discussed the Application of Rapid Application Development to online bicycle sales systems. The aim of the research is to produce an online bicycle sales system through database integration and building relationships with customers more personally. The purpose was to expand marketing reach and increasing sales through media that are more flexible and more economical. The system modeling used UML (Unified Modeling Language). Userdesired content and relevant to intuitive, user-friendly design is very important to motivate individuals to use e-learning programs (Stotz \& Lee, 2018). eLearning has become a promising solution for the world of Education, which is currently in an environment of intense changes in the application of information technology as one of the most effective and efficient factors (Popovici \& Mironov, 2015).

The research conducted Maulina and Bernadhed, the website-based e-learning information system that was built to be able to help the process of teaching and learning activities in Syubbanul Wathon Tegalrejo Vocational School became more optimal (Maulina \& Bernadhed, 2017). This method has made it easier for teachers to be able to deliver subject matter, conduct online quizzes, provide school info quickly, collect student assignments online, and consult students whenever and wherever without any space and time limits. current eLearning trends-Massive Open Online Courses (MOOCs), tablet computing, and learning analytics (Doherty et al., 2015). The success of e-learning programs in information technology (IT) affects the level of online student satisfaction and their intention to continue using e-learning systems, as important or more important than effective VLE design in an IT context, (Hayashi et al., 2020). In e-learning systems, it is necessary to stimulate users to spend more time in the system to achieve the quantity and volume of practical skills needed (Bubnov et al., 2015). e-Learnings defined as instruction that is delivered via a digital device that is intended to promote learning. he digital device can be any electronic device that is controlled by a computer chip, including desktop computer, laptop computer, tablet, smartphone, game console or wearable devices such as head mounted virtual reality displays (Mayer, 2017). Increasing the use of multimedia in Education is related to the use of Internet technology (e.g. greater bandwidth and wireless Internet connections). In addition, technology will greatly affect the delivery of online learning, (ElSeoud et al., 2014). In addition, the decision of students to adopt e-learning is not in accordance with their wishes with related technology. Students who are very friendly with various types of technology may or may not have a positive perception of e-learning (Ngampornchai \& Adams, 2016).

The e-school system can improve academic services for students and parents of students to access student grades, student attendance data, teacher data, and other things related to filial school academics, which have been performed manually by the school and 
LPKA Class I Palembang. Based on several previous studies, this study resulted in an eschool learning system that emphasized the functions and needs of the LPKA Class I Palembang by applying the Rapid Application Development method. RAD is an objectoriented approach to system development that includes a method of development and software. Three phases in RAD that involve the analyzer and the user in the stages of assessment, design, and implementation (Kendall \& Kendall, 2010) This research aims to build e-school learning systems in filial schools implemented in LPKA Class I Palembang.

\section{Method}

The research location was Filial School at the LPKA Class I Palembang, Data Collection Techniques: 1). Observation, According to (Saputra, 2012) observation is a direct observation of the activities being carried out, system analysts can also participate or just observe the people who are doing certain activities observed. The researcher made direct observations and was also involved in activities in LPKA Class 1 Palembang related to the development and implementation of e-School. 2). Literature Study, According to (Sutabri, 2012), literature study is a data collection technique conducted by researchers by examining the theories of opinion and the main points of thought contained in print media, especially books that support and are relevant to problems in research. In library studies using data collection techniques by reading, recording, and studying three materials related to the development and implementation of e School.

The system development method used was the RAD method. RAD is an objectoriented approach to system development that includes a method of development and software. Three phases in RAD that involve the analyzer and the user in the stages of assessment, design, and implementation (Kendall \& Kendall, 2010). According to (Wijaya et al., 2015), the RAD stage consists of 3 phases: 1). Requirements Planning, namely: Users and analysts meet to identify the objectives of the system and Oriented to problem-solving. 2). RAD Design Workshop, namely: Design and refinement phase, Programmers and analysts build and show a visual display of the user's design and workflow, the user responds to the actual work prototype, and Analysts perfect modules designed based on user responses. 3). Implementation, namely: As a new system is built, a new or partial system is tested and introduced to the organization and When creating a new system, there is no need to run the old system in parallel. Rapid Application Development (RAD) is a methodology used to develop software. This method is able to reduce time to develop software. RAD is a set of methods developed to overcome the weaknesses of traditional system development methods, such as waterfall models and their variants (Delima et al., 2017).

Testing structural program can utilize White Box, Black Box, or Gray testing methods, and Black Box Testing by conducting testing only on the existing system function (Syaikhuddin et al., 2018). a key point of black-box testing is design of boundary / subboundary testing case for data inputting type. Black-box testing mainly used in unit phase, integration phase, validation phase, and verification phase (TanLi et al., 2020). Alpha Testing was carried out by system developers, which will be carried out by the Testing Division. Software Testing used the Black Box Testing Method carried out by the LPKA Coordinator, the umbrella school coordinator, and the teacher. The Black Box testing method was applied 
to acceptance testing level, which is to test whether the software is in accordance with user needs. The flow of e-school system analysis shown in Figure 1.

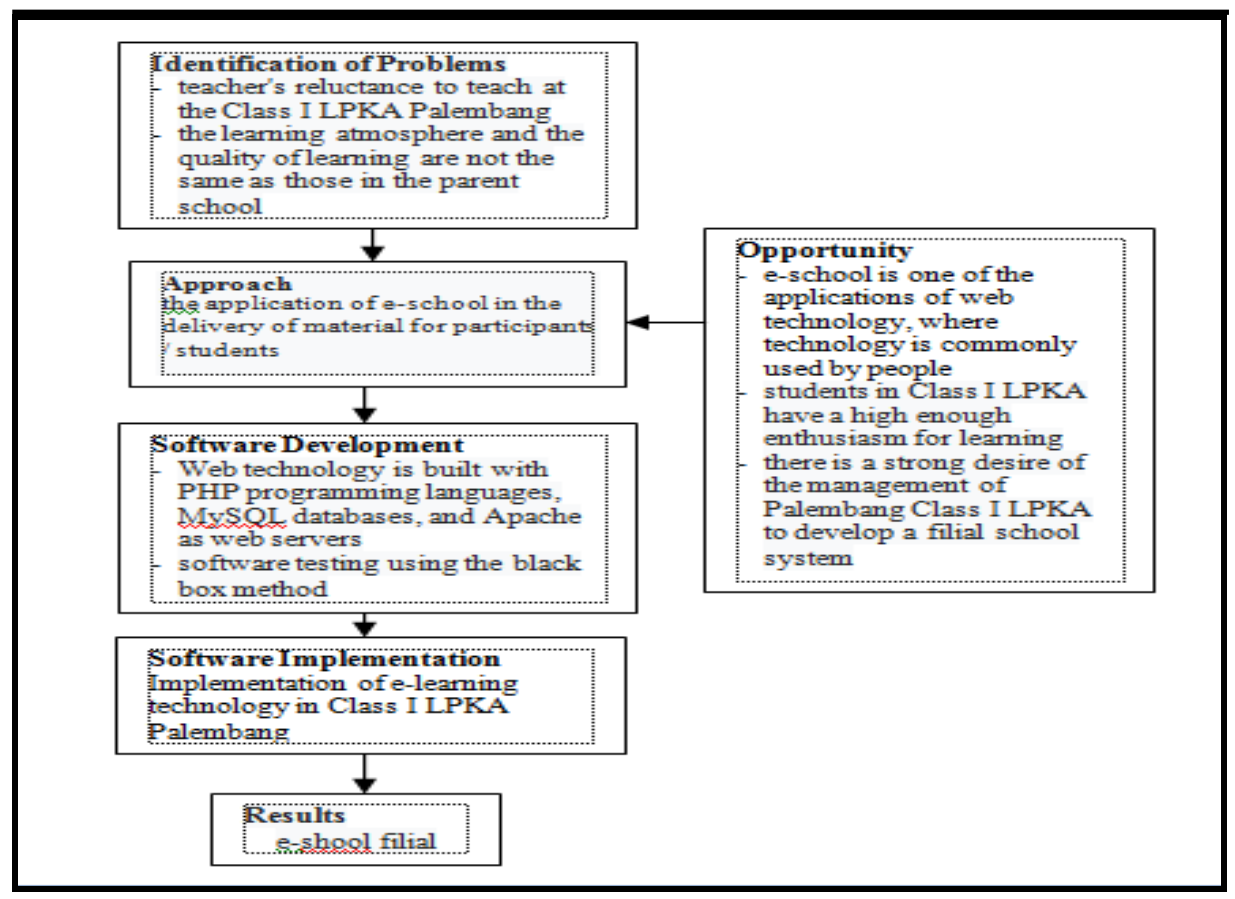

Figure 1. Flow of e-school Filial development analysis

Figure 1 explains the flow of analysis starting from Problem Identification $\rightarrow$ Opportunities / Approaches $\rightarrow$ Software Development $\rightarrow$ Software Implementation $\rightarrow$ Results.

Unified Modelling Language (UML) is an image notation used as a visual language to explain, describe, construct, and document the components needed in a software system and business model (Setianingsih et al., 2019). Presumption of a clear representation of requirements and proper implementation of the evolutionary prototype in this step of the prototyping process that suggests using so-called "use cases", modeled by UML activity diagram. Use cases are focused on the objectives of users, making them suitable tool for a description of the prototype. Figure 2 shown the context diagram of the eschool system based on (Nacheva, 2017). 


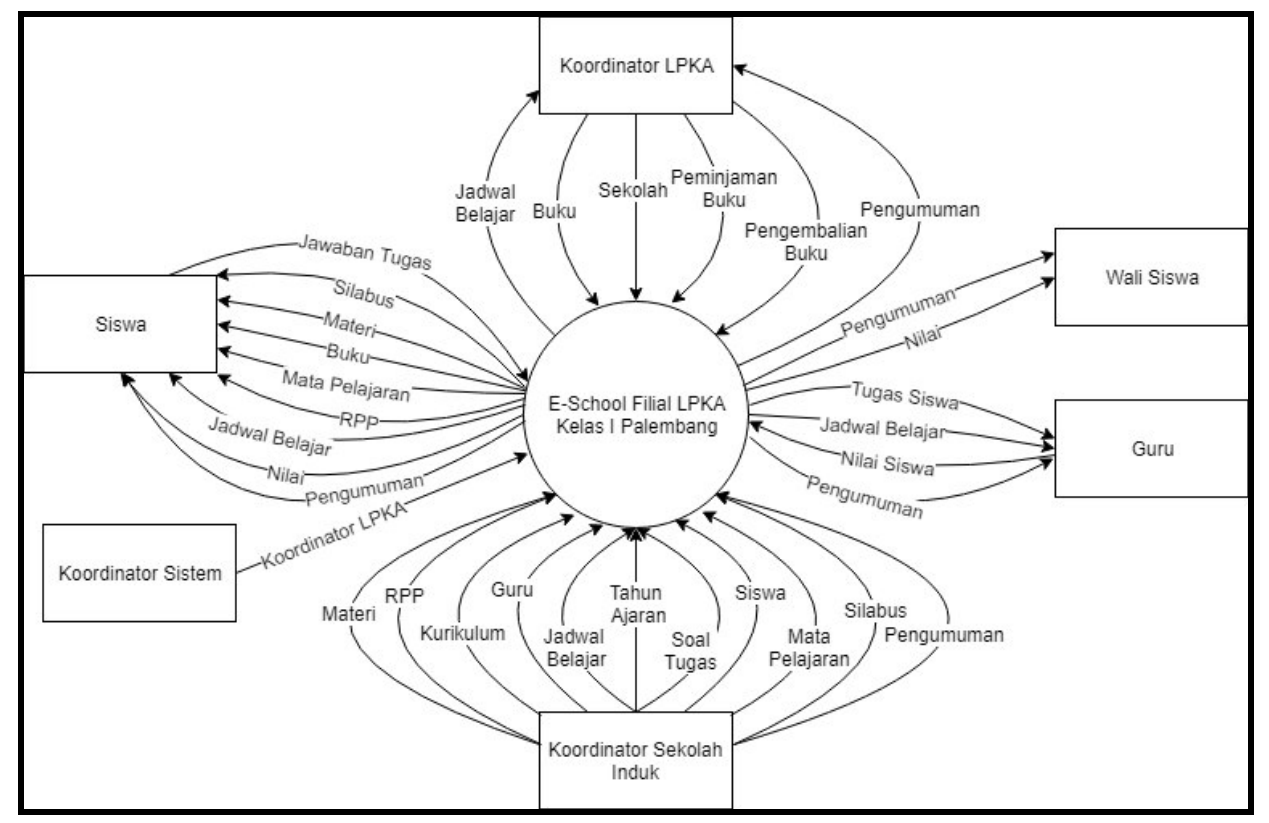

Figure 2. Context Diagram

Based on Figure 2. there are 6 entities, namely: LPKA coordinator, student, system coordinator, umbrella school coordinator, teacher, and parents.

\section{Result and Discussion Results}

This invention is about web-based software that facilitates teaching and learning activities between LPKA Class I Palembang children and teachers from the umbrella school for compulsory education at the elementary, middle and high school levels. This is so that learning and teaching activities run without the teacher coming directly to the LPKA Class I Palembang, so this e-school system facilitates online-based learning and teaching media with the subject matter in pdf, video, audio and also distance learning classes directly and real-time with WebRTC (Web Real-Time Communication) technology. The e-school system with the link address http://e-schoolfiliallpka.com/ also provides task control facilities provided to students so that the teacher can check directly on students who have collected assignments and are accompanied by online discussion forums. This application facilitates the learning process of LPKA Class I Palembang children to be able to learn independently with existing media and facilitate teachers in delivering the learning material. 


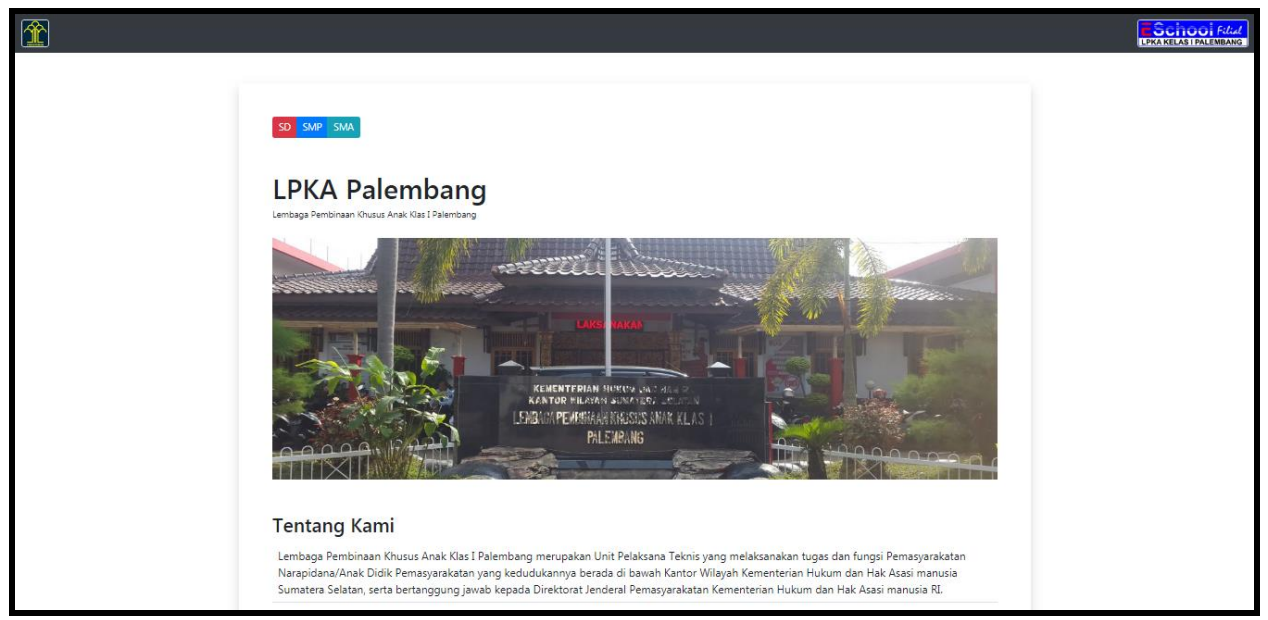

Figure 3. Main Page of e-school

E-school Filial LPKA Class I Palembang that has been built consists of a. Videobased learning module, b. Audio-based learning module, c. Text-based learning module, $d$. Media for distance learning, e. Assignment and submission media, f. Discussion media. This electronic school application emphasizes the learning process which consists of (1) electronic book-based learning modules (e-books), (2) video-based learning modules, (3) audio-based learning modules, (4) teleconference classes between teachers and participants in class, (5) assignment for student by the teacher, (6) submission of assignments by students, and (7) discussion forums between students and teachers to discuss assignments and material.

\section{Discussion}

The filial e-school system that has been implemented in LPKA Class I Palembang has been able to overcome the problems faced in teaching and learning activities that have traditionally been done to be more effective because it has switched to web-based electronic media. The results of this study can also be used by LPKA in other regions or provinces who will also implement filial schools. E-schools create effective learning because they have used information and communication technology in the learning process as a tool. This e-school system facilitates the learning process of LPKA students to be able to learn independently with existing media and make it easier for teachers to deliver learning material (Octafian et al., 2020). The e-school filial system has been able to support better education delivery and improvement of academic services in the LPKA Class I Palembang filial school which provides: a. Video-based learning module, b. Audio-based learning module, c. Text-based learning module, $\mathrm{d}$. Distance learning media, e. Media giving assignments and gathering student assignments, and f. Discussion media, (Febrianty et al., 2019). As in Research (Maulina \& Bernadhed, 2017) about the development of e-learning systems and also (Wahyudi \& Diana, 2012) about e-schools, which discuss e-school systems that provide teachers to provide learning material, conduct online quizzes, provide school info with 
quickly, collect student assignments online, and collect with students anytime and anywhere without space and time restrictions.

Innovative methods in pedagogy developed in e-learning systems, by assessing the effectiveness of the system based on log file analysis to track learning time, number of connections, and the main features of the system developed include teaching and learning material that has been synchronized (Osipov et al., 2015). E-school has shown that appropriate applications of technology greatly enhance learning. Through the use of advanced computing and telecommunications technology, learning can also be qualitatively different. The process of learning in the classroom can become significantly richer as students have access to new and different types of information, can manipulate it on the computer through graphic displays or controlled experiments in ways never before possible, and can communicate their results and conclusions in a variety of media to their teacher, students in the next classroom. A more recent study found that online learning allows individual student needs to be more effectively met and instructors have more time to address individual student learning issues (Florence, 2017). There is a need to better understand what constitutes an effective website that provides a school with an avenue for delivering innovation in teaching and learning, and complements how a school operates. The framework and suggested recommendations promote a holistic approach when developing a website to accurately portray a school's identity and effectively address stakeholders' needs (Taddeo \& Barnes, 2016). There is a significant significance between e-learning experiences in the Learning Process, which means an increase in the quality of learning that can be done by improving the learning process that first increased because the learning experience has no direct effect (Azis et al., 2019).

\section{Conclusions}

This research resulted in a special e-school system that was used to help the learning process and improve academic coaching in LPKA Palembang who submitted schools, making this System easier for LPKA Class I Palembang and the schools that handled it to find the information they needed. This system will provide benefits if Palembang LPKA Class I management and schools play a consistent/ongoing role. In addition, based on the level of Electronic Filial Technology Readiness (TKT) in this study, it can be implemented optimally in LPKA Class I Palembang and become a reference/model for other regional LPKA.

\section{Acknowledgment}

Gratitude to the Directorate of Research and Community Service of the Directorate General of Research and Development, the Ministry of Research, Technology and Higher Education which has funded this Applied Research (funding in 2019). So is with the management, especially the LPPM Polytechnic Palcomtech, which has provided convenience and helped to facilitate the implementation of this applied research. 


\section{References}

Ali, M. (2009). Pendidikan Untuk Pembangunan Nasional. Penerbit INTIMA.

Azis, Y. M., Suharyati, H., \& Susanti, S. (2019). Student's Experience Of E-Learning, Learning Process And Perceived Learning Outcomes In Economic Math Course. JHSS (Journal of Humanities and Social Studies), 3(2), 67-71. https://journal.unpak.ac.id/index.php/jhss

Bubnov, G., Nikulchev, E., \& Pluzhnik, E. (2015). Experience the effective implementation of innovative information technologies in educational institute. Vysshee Obrazovanie $v$ Rossii [Higher Education in Russia], 1, 159-161. https://vovr.elpub.ru/jour/article/view/118?locale=en_US

Cidral, W. A., Oliveira, T., Felice, M. Di, \& Aparicio, M. (2018). E-learning success determinants: Brazilian empirical study. Computers \& Education, 122, 273-290. https://doi.org/10.1016/j.compedu.2017.12.001

Delima, R., Santosa, H. B., \& Purwadi, J. (2017). Development of Dutatani Website Using Rapid Application Development. IJITEE (International Journal of Information Technology and Electrical Engineering), 1(2), 36-44. https://doi.org/10.22146/ijitee.28362

Doherty, I., Sharma, N., \& Harbutt, D. (2015). Contemporary and future eLearning trends in medical education. Medical Teacher, 37(1), 1-3. https://doi.org/10.3109/0142159X.2014.947925

El-Seoud, M. S. A., Taj-Eddin, I. A. T. F., Seddiek, N., El-Khouly, M. M., \& Nosseir, A. (2014). E-Learning and Students' Motivation: A Research Study on the Effect of E-Learning on Higher Education. IJET, 9(4). https://doi.org/10.3991/ijet.v9i4.3465

Febrianty, F., Hadiwijaya, H., \& Octafian, D. T. (2019). Monograf E-School Filial LPKA Kelas 1 Palembang. PT. Nasya Expanding Management.

Florence, M. (2017). New revolution in education-digital classroom. The Online Journal of Distance, 5(1), 66-68. https://tojdel.net/journals/tojdel/articles/v05i01/v05i01-09.pdf

Gilbert, S., \& Jones, S. (2011). E-learning is e-normous: Training over the Internet has become the fastest growing workplace performance improvement tool and utilities are using it in several ways. Electric Perspectives, 26(3), 66-82.

Hayashi, A., Chen, C., Ryan, T., \& Wu, J. (2020). The Role of Social Presence and Moderating Role of Computer Self Efficacy in Predicting the Continuance Usage of ELearning Systems. Journal of Information Systems Education, 15(2), 5. https://aisel.aisnet.org/jise/vol15/iss2/5/

Kendall, K. E., \& Kendall, J. E. (2010). Analisis dan Perancangan Sistem. Indeks.

Kosasi, S., \& Yuliani, I. D. A. E. (2015). Penerapan Rapid Application Development Pada Sistem Penjualan Sepeda Online. Jurnal Simetris, 6(1). https://doi.org/10.24176/simet.v6i1.234

Maulina, D., \& Bernadhed. (2017). Perancangan Sistem Informasi E-Learning Pada SMK 
Syubbanul Wathon Tegalrejo Magelang. Jurnal Ilmiah Dasi: Data Manajemen DanTeknologi Informasi, 18(1).

Mawardi, S., Satria, E., \& Tresnawati, D. (2012). Perancangan Web Kelas Online Dengan Metodologi WISDM Berbasis Learning Manajement System di MAN Pameungpeuk. Jurnal Algoritma, 9(37). https://doi.org/10.33364/algoritma/v.9-2.307

Mayer, R. E. (2017). Using multimedia for e-learning. In Journal of Computer Assisted Learning. https://doi.org/10.1111/jcal.12197

Nacheva, R. (2017). Prototyping Approach In User Interface. June, 80-87.

Ngampornchai, A., \& Adams, J. (2016). Students' acceptance and readiness for E-learning in Northeastern Thailand. International Journal of Educational Technology in Higher Education, 13(34). https://doi.org/10.1186/s41239-016-0034-x

Octafian, D. T., Febrianty, \& Hadiwijaya, H. (2020). User Experience Analysis on Class I LPKA Palembang Filial E-School User Experience Analysis on Class I LPKA Palembang Filial. Journal of Physics: Conference Series, 1500, 1-8. https://doi.org/10.1088/1742-6596/1500/1/012126

Osipov, I. V., Volinsky, A. A., Nikulchev, E., \& Prasikova, A. Y. (2015). Study of Gamification Effectiveness in Online e-Learning Systems. International Journal of Advanced Computer Science and Applications, 6(2), 71-77. https://doi.org/10.14569/ijacsa.2015.060211

Popovici, A., \& Mironov, C. (2015). Students' Perception on Using eLearning Technologies. Procedia - Social and Behavioral Sciences, 180(November 2014), 1514-1519. https://doi.org/10.1016/j.sbspro.2015.02.300

Putra, D. P. A., Mursityo, Y. T., \& Pramono, D. (2019). Pengembangan Sistem Informasi Akademik Siswa Pada Sekolah Berbasis Asrama (Studi Pada Tazkia International Islamic Boarding School Malang). Jurnal Pengembangan Teknologi Informasi Dan IImu Komputer, 3(3), 2814-2822.

Saputra, A. (2012). Membuat Aplikasi Absensi Dan Kuesioner untuk Panduan Skripsi. PT. Elex Media Koputindo.

Setianingsih, F., Permanasari, A. E., \& Najib, W. (2019). Management Information System of the Billing Subsystem: A Prototype Design. IJITEE (International Journal of Information Technology and Electrical Engineering), 3(2), 59. https://doi.org/10.22146/ijitee.49424

Soekartawi. (2007). Merancang dan Menyelenggarakan e-Learning. Yogyakarta: Ardana Media Perancangan E-School Berbasis Web (Studi Kasus: SMP IT Future Islamic School Pekanbaru).

Stotz, S., \& Lee, J. S. (2018). Development of an Online Smartphone-Based eLearning Nutrition Education Program for Low-Income Individuals. Journal of Nutrition Education and Behavior, 50(1), 90-95.e1. https://doi.org/10.1016/j.jneb.2016.12.008

Sutabri. (2012). Koleksi Program tugas akhir dan skripsi dengan FoxPro9. PT. Alex Media 
Komputindo.

Syaikhuddin, M. M., Anam, C., Rinaldi, A. R., \& Conoras, M. E. B. (2018). Conventional Software Testing Using White Box Method. Kinetik, 3(1), 67. https://doi.org/10.22219/kinetik.v3i1.231

Taddeo, C., \& Barnes, A. (2016). The school website: Facilitating communication engagement and learning. British Journal of Educational Technology (BJET), 47(2), 223-436. https://doi.org/10.1111/bjet.12229

TanLi, M., Jiang, Y., Wang, X., \& Peng, R. (2020). Black-box approach for software testing based on fat-property. MATEC Web of Conferences, 309, 02008. https://doi.org/10.1051/matecconf/202030902008

Twin, A. (2017). Mewujudkan Sekolah Inklusi Merujuk Pada Pendidikan Untuk Semua. Www.Kompasiana.Com.

https://www.kompasiana.com/twin/5a00470dc226f97a1a0f8482/mewujudkan-sekolahinklusi-merujuk-pada-pendidikan-untuk-semua?page=all

Wahyudi, \& Diana, R. (2012). Perancangan E-School Berbasis Web (Studi Kasus: SMP IT Future Islamic School Pekanbaru. Jurnal Sains, Teknologi Dan Industri, 9(2).

Widhiartha, P. A. (2009). Pemanfaatan E-Learning Sebagai Alternatif Pengganti Pelatihan Tatap Muka Bagi Pendidik Dan Tenaga Kependidikan Pendidikan Nonformal. Jurnal IImiah VISI PTK-PNF, 4(2), 189-196. https://doi.org/10.21009/JIV.0402.7

Wijaya, K., Wowor, H., \& Tulenan, V. (2015). Sistem Pendukung Keputusan Penerima Beasiswa dengan Metode Technique For Order Preference By Similarity To Ideal Solution Di Universitas Sam Ratulangi Manado. Jurnal Teknik Informatika, 5(1). https://doi.org/10.35793/jti.5.1.2015.8312 